\title{
PENGARUH INFLASI DAN PRODUK DOMESTIK BRUTO (PDB) TERHADAP TINGKAT SUKU BUNGA RIIL DENGAN MENGGUNAKAN PENDEKATAN TAYLOR RULE
}

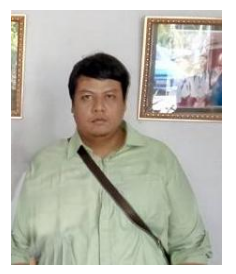

\author{
Oleh : \\ Hendry Wijaya \\ Staf Pengajar STIE Rahmaniyah Sekayu \\ Email : hendrywijaya2001@gmail.com
}

\begin{abstract}
Abstraksi
Penelitian ini berfokus kepada kebijakan moneter khususnya analisis kebijakan moneter dengan menggunakan pendekatan "Taylor Rule" Penelitian ini bertujuan untuk mengetahui pengaruh Inflasi Dan Produk Domestik Bruto (PDB) Terhadap Tingkat Suku Bunga Riil Dengan Menggunakan Pendekatan Taylor Rule. Hasil penelitian ini menunjukkan bahwa bahwa Variabel Bebas (Inflasi dan Output) berpengaruh negative slope terhadap Variabel Terikat (Tingkat Suku Bunga Riil), hal ini berarti setiap kenaikan nominal pada variable Inflasi dan Output maka akan menyebabkan tingkat suku bunga riil akan turun. Hasil penelitian ini menjelaskan bahwa Variable bebas mampu untuk menjelaskan variable terikat sebesar 0,240 atau 24\%, dan terdapat $76 \%$ variabel lain yang dapat juga menjelaskan variabel terikat tetapi tidak dimasukkan kedalam uji model pada penelitian ini. Untuk uji hipotesis, variable bebas tidak berpengaruh secara signifikan terhadap variable terikat.
\end{abstract}

Kata Kunci :Kebijakan Moneter Dengan Pendekatan Taylor Rule, Inflasi, BI Rate, Produk Domestik Bruto (PDB)

\section{Pendahuluan.}

\subsection{Latar Belakang}

Indikator kesuksesan dalam pengelolaan perekonomian suatu Negara ditandai oleh terjadinya pertumbuhan ekonomi kearah peningkatan ekonomi.Hal ini mengidikasikan bahwa semakin tinggi kenaikan tingkat pertumbuhan perekonomian suatu Negara, maka kemakin baik kondisi perekonomian Negara tersebut. Pertumbuhan yang terjadi pada perekonomian suatu Negara akan berdampak kepada peningkatan kesejahteraan masyarakat pada Negara tersebut yaitu pendapatan nasional.

$$
\text { Peningkatan kesejahteraan }
$$

masyarakat dapat yang diukur melalui pendapatan nasional sebagai proksi dari pertumbuhan ekonomi suatu Negara merupakan tujuan dari perekonomian suatu Negara. Pendapatan nasional sering diartikan sebagai Produk Domestic Bruto (PDB) yang sering digunakan sebagai salah satu pengukuran tingkat pendapatan nasional suatu Negara, dengan menghitung nilai barang dan jasa (output) yang dihasilkan oleh aktifitas perekonomian suatu Negara dalam kurun waktu dan periode tertentu.

Menurut Todaro (1998) dalam Murwani (2007) mengatakan bahwa pertumbuhan merupakan tema sentral dalam kehidupan ekonomi pada hampir semuanegaradewasa ini. Dari beberapa faktor pertumbuhan ekonomi yang umum dapat dikatakan bahwa salah-satu sumber utama bagi pertumbuhan ekonomi adalah adanya investasi yang mampu memperbaiki kualitas modal atau sumber daya manusia dan fisik, yang selanjutnya akan berhasil meningkatkan kualitas sumber daya melalui penemuan-penemuan baru, inovasi, dan kemajuan teknologi. Pendapat yang dikemukakan oleh Rostow dalam bukunya yang terkenal The Stages of Economic Growth, dalam Murwani 
(2007) bahwa salah-satu dari sekian banyak taktik pokok pembangunan untuk tinggal landasadalah pengerahan atau mobilisasi dana tabungan (dalam mata uang domestik maupun asing) guna menciptakan investasi dalam jumlah yang memadai untuk mempercepat laju pertumbuhan ekonomi.

Fundamental ekonomi yang tercermin dari kondi sistabilitas makroekonomi negara merupakan salah satu faktor yang diperhitungkan oleh investor asing. Stabilitas nilai tukar, tingkat bunga dan tingkat harga merupakan indikator dari stabilitas moneter menetapkan suatu target inflasi sebagai acuan dalam pelaksanaan kebijakan moneter Bank Indonesia.

Konsekuensi penetapan kebijakan inflation targeting adalah bagaimana kebijakan moneter tersebut dapat dijalankan untuk mencapai tujuan tersebut baik dari sisi target operasional, target antara atau variabel informasi dan juga bagaimana mekanisme transmisi kebijakan tersebut dapat mempengaruhi output riil dan harga.

Berdasarkan latar belakang diatas, maka peneliti berminat untuk melakukan penelitian dengan judul "Pengaruh Inflasi Dan Produk Domestik Bruto (PDB) Terhadap Tingkat Suku Bunga Riil Dengan Menggunakan Pendekatan Taylor Rule"

\subsection{Rumusan Masalah}

Berdasarkan latar belakang diatas, maka rumusan penelitian ini adalah :

a. Bagaimana pengaruh Inflasi Dan Produk Domestik Bruto (PDB) Terhadap Tingkat Suku Bunga Riil Dengan Menggunakan Pendekatan Taylor Rule. b. Seberapa besar Variabel Bebas (Inflasi Dan Produk Domestik Bruto) mampu menjelaskanVariabel Terikat (Tingkat Suku Bunga Riil) Dengan Menggunakan Pendekatan Taylor Rule.

\subsection{Manfaat Penelitian}

Hasil penelitian ini diharapkan sangat berguna bagi pengembangan ilmu pengetahuan. Disamping bermanfaat dalam pengembangan ilmu pengetahuan, penelitian ini diharapkan dapat memberi masukan kepada pengambil kebijakan. Manfaat yang diharapkan dari penelitian ini meliputi manfaat pengembangan ilmu dan manfaat praktis dapat diuraikan sebagai berikut:

\section{a. Manfaat Teoritis}

Manfaat pengembangan ilmu, hasil penelitian ini memberi variasi tentang hasil-hasil studi tentang ekonomi makro khususnya kajian kebijakan moneter terutama tentang konsep moneter dengan menggunakan pendekatan Taylor Rule.

b. Manfaat Praktis

a. Bagi Instansi Pemerintah, hasil dari penelitian ini dapat dijadikan sebuah masukan atau informasi mengenai dampak Inflasi Dan Produk Domestik Bruto (PDB) Terhadap Tingkat Suku Bunga Riil.

b. Bagi institusi pendidikan tinggi dan akademis diharapkan hasil penelitian ini dapat menambah referensi dan informasi mengenai dampak Inflasi Dan Produk Domestik Bruto (PDB) Terhadap Tingkat Suku Bunga Riil.

\subsection{Tujuan Penelitian}

Penelitian ini dilakukan dengan tujuan :

a. Untuk Mengetahui bagaimana pengaruh Inflasi Dan Produk Domestik Bruto (PDB) Terhadap Tingkat Suku 
Bunga Riil Dengan Menggunakan Pendekatan Taylor Rule.

b. Untuk Mengetahui seberapa besar Inflasi Dan Produk Domestik Bruto (PDB) Terhadap Tingkat Suku Bunga Riil Dengan Menggunakan Pendekatan Taylor Rule.

\section{Tinjauan Pustaka}

\subsection{Konsep Taylor Rules}

Dalam penulisan ini kami akan membahas mengenai aplikasi persamaan linier tingkat suku bunga bank sentral dan inflasi yang dikemukakan oleh Taylor. Dalam menanggapi kebijakan moneter yang dilakukan oleh pihak pemerintah, menurut Taylor (dalam Romer, 2006) mempunyai argument sebagai dasar panduan mengenai tingkat suku bunga dan inflasi, yaitu :

a. Untuk kenaikan tingkat bunga nominal lebih dari satu-untuk-satu dengan inflasi, hal ini akan menyebabkan kenaikan tingkat bunga riil terjadi ketika terjadi kenaikan pada inflasi.

b. Untuk tingkat suku bunga akan naik ketika output diatas normal, dan sebaliknya, tingkat suku bunga akan turun apabila output berada dibawah normal.

Selain dari argument diatas, Taylor dalam Romer (2006) menggambarkan keterkaitan linear melalui fungsi linear inflasi dan pergerakan persentase output dari natural rate-nya, melalui persamaan 1. dan persamaan 2, yaitu:

$i_{t}-\pi_{t}=a+b \pi_{t}+c\left(\ln Y_{t}-\ln \bar{Y}_{t}\right)$ ..(1)

Asumsi Taylor Rule :

Apabila $\overline{\boldsymbol{r}}_{\boldsymbol{t}}$ didefinisikan sebagai tingkat suku bunga riil yang akan berlaku apabila kondisi $\boldsymbol{Y}_{\boldsymbol{t}}=\overline{\boldsymbol{Y}}_{\boldsymbol{t}}$ dan jika diasumsikan bahwa hal tersebut dinyatakan konstan dari waktu kewaktu. Sehingga apabila asumsi tersebut digunakan, maka persamaan 1akan sama dengan persamaan 2. seperti tergambar dibawah ini :

$i_{t}-\pi_{t}=\bar{r}+b\left(\pi_{t}-\pi^{*}\right)+c\left(\ln Y_{t}-\ln \right.$

$\left.\overline{\boldsymbol{Y}}_{t}\right) \ldots(\mathbf{2})$

Dimana diasumsikan, $\overline{\boldsymbol{r}}=(\overline{\boldsymbol{r}}-\boldsymbol{a}) / \boldsymbol{b}$.

Keterangan Persamaan (1):

$i_{t}-\pi_{t} \quad$ :Tingkat Suku Bunga Riil.

a $\quad$ Konstanta.

$\boldsymbol{b} \pi_{t} \quad:$ Koefisien Inflasi..

$c\left(\ln Y_{t}-\ln \bar{Y}_{t}\right) \quad:$ Koefiesien Output.

Persamaan diatas merepresentasikan ketentuan bahwa Bank Sentral harus menaikkan tingkat suku bunga riil diatas tingkat kesimbangan jangka panjang pada saat inflasi melebihi target dan output melebihi natural rate nya.Ketentuan yang digambarkan dalam persamaan $1 \& 2$, biasa dikenal dengan sebutan Taylor Rule.

\subsection{Kerangka Pikir Penelitian}

Untuk mempermudah dalam membaca dan memahami alur piker daam penelitian ini, maka disajikan konsep kerangka piker penelitian yang tersaji sebagai berikut:

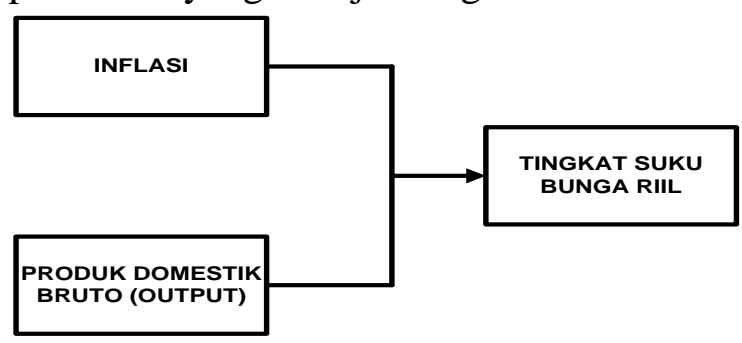

Gambar 1

Kerangka Pikir Penelitian

\section{Metodologi Penelitian}

\subsection{Objek dan Waktu Penelitian}

Bahan kajian penelitian yang dijadikan dalam objek kajian pada penelitian adalah tingkat suku bunga, output (PDB), Inflasi. Penelitian ini dilakukan pada bulan februari - maret tahun 2015 .

\subsection{Populasi dan Sampel}

\section{a. Populasi}

Populasi penelitian ini adalah tingkat suku bunga, output (PDB), Inflasi. 


\section{b. Sampel}

Populasi penelitian ini adalah tingkat suku bunga, output (PDB), Inflasi hanya pada tahun 2014 .

\subsection{Jenis Data}

Penelitian ini menggunakan data sekunder yang didapat dari lembaga/institusi penyedia data yang terkait dengan penelitian yang dalam hal ini lembaga tersebut adalah Bank Indonesia dan Badan Pusat Statistik.

\subsection{Teknik Pengumpulan Data}

a. Dokumentasi

b. Studi Kepustakaan

\subsection{Teknik Analisis Data}

Penelitian ini menggunakan teknik analsis kuatitatifdengan menggunakan metode OLS (Ordinary Least Square).Menurut Gujarati dan Porter (2009).Ordinary least square (OLS) merupakan metode estimasi yang sering digunakan untuk mengestimasi fungsi regresi populasi dan fungsi regresi sampel. Kriteria OLS adalah "line best fit" atau jumlah kuadrat dari deviasi antara titik-titik observasi dengan garis regresi adalah minimum. Metode OLS yang akan digunakan adalah :
a. Uji Regresi Berganda Logaritma Natural.
b. Uji Hipotesis.
c. Uji Koefisien Determinasi.

\section{Pembahasan}

\subsection{Data}

Dalam menganalisis persamaan yang dikemukakan didalam konsep dasar Taylor Rule, akan diimplementasikan dengan menggunakan beberapa data time series berikut ini : a. Data Tingkat Suku Bunga Riil

\begin{tabular}{|c|c|c|}
\hline NO & TAHUN & BI RATE \\
\hline 1 & 2005 & 12,75 \\
\hline 2 & 2006 & 9,75 \\
\hline 3 & 2007 & 8 \\
\hline 4 & 2008 & 9,25 \\
\hline 5 & 2009 & 6,50 \\
\hline 6 & 2010 & 6,50 \\
\hline 7 & 2011 & 6 \\
\hline 8 & 2012 & 5,75 \\
\hline 9 & 2013 & 7,50 \\
\hline
\end{tabular}

Sumber : Bank Indonesia, 2014.

b. Data Inflation

\begin{tabular}{|c|c|c|}
\hline No. & Tahun & Nominal Inflasi \\
\hline 1 & 2005 & 17.11 \\
\hline 2 & 2006 & 6.6 \\
\hline 3 & 2007 & 6.59 \\
\hline 4 & 2008 & 11.06 \\
\hline 5 & 2009 & 2.78 \\
\hline 6 & 2010 & 6.96 \\
\hline 7 & 2011 & 3.79 \\
\hline 8 & 2012 & 4.3 \\
\hline 9 & 2013 & 8.38 \\
\hline
\end{tabular}

Sumber : Bank Indonesia, 2014.

\section{c. Data Output (PDB)}

- PDB Harga Berlaku Di Indonesia.

\begin{tabular}{|c|c|c|}
\hline No. & Tahun & $\begin{array}{c}\text { PRODUK DOMESTIK } \\
\text { BRUTO }\end{array}$ \\
\hline 1 & 2005 & Rp $\quad \mathbf{2 , 7 7 4 , 2 8 1 , 1 0 0 , 0 0 0 , 0 0 0 . 0 0}$ \\
\hline 2 & 2006 & Rp $\quad \mathbf{3 , 3 3 9 , 2 1 6 , 8 0 0 , 0 0 0 , 0 0 0 . 0 0}$ \\
\hline 3 & 2007 & Rp $\quad \mathbf{3 , 9 5 0 , 8 9 3 , 2 0 0 , 0 0 0 , 0 0 0 . 0 0}$ \\
\hline 4 & 2008 & Rp $\quad \mathbf{4 , 9 4 8 , 6 8 8 , 4 0 0 , 0 0 0 , 0 0 0 . 0 0}$ \\
\hline 5 & 2009 & Rp $\quad \mathbf{5 , 6 0 6 , 2 0 3 , 4 0 0 , 0 0 0 , 0 0 0 . 0 0}$ \\
\hline 6 & 2010 & Rp $\quad \mathbf{6 , 4 4 6 , 8 5 1 , 9 0 0 , 0 0 0 , 0 0 0 . 0 0}$ \\
\hline 7 & 2011 & Rp $\quad \mathbf{7 , 4 1 9 , 1 8 7 , 1 0 0 , 0 0 0 , 0 0 0 . 0 0}$ \\
\hline 8 & 2012 & Rp $\quad \mathbf{8 , 2 2 9 , 4 3 9 , 4 0 0 , 0 0 0 , 0 0 0 . 0 0}$ \\
\hline 9 & 2013 & Rp $\quad \mathbf{9 , 0 8 3 , 9 7 2 , 2 0 0 , 0 0 0 , 0 0 0 . 0 0}$ \\
\hline
\end{tabular}

Sumber : BPS, Indonesia, 2014. 
- PDB Harga Konstan Di Indonesia.

\begin{tabular}{|c|c|c|}
\hline No. & Tahun & $\begin{array}{c}\text { PRODUK DOMESTIK } \\
\text { BRUTO }\end{array}$ \\
\hline 1 & 2005 & Rp $1,750,815,200,000,000.00$ \\
\hline 2 & 2006 & Rp $1,847,126,700,000,000.00$ \\
\hline 3 & 2007 & Rp 1,964,327,300,000,000.00 \\
\hline 4 & 2008 & Rp 2,082,456,100,000,000.00 \\
\hline 5 & 2009 & Rp 2,178,850,400,000,000.00 \\
\hline 6 & 2010 & Rp 2,314,458,800,000,000.00 \\
\hline 7 & 2011 & Rp 2,464,566,100,000,000.00 \\
\hline 8 & 2012 & Rp 2,618,938,400,000,000.00 \\
\hline 9 & 2013 & Rp 2,770,345,100,000,000.00 \\
\hline
\end{tabular}

Sumber : BPS, Indonesia, 2014.

a. Uji Regresi Variabel

\subsection{Analisis Data}

Dalam menganalisis data pada penelitian ini menggunakan metode analisis data kuantitatif dengan cara mengestimasi data dengan menggunakan Metode Regresi Berganda, Uji Koefisien Determinasi $\left(\mathrm{R}^{2}\right)$, Uji Hipotesis Data.

\begin{tabular}{|ll|r|r|r|r|r|}
\hline \multirow{2}{*}{ Model } & \multicolumn{2}{|c|}{$\begin{array}{c}\text { Unstandardized } \\
\text { Coeff icients }\end{array}$} & \multicolumn{2}{c|}{$\begin{array}{c}\text { Standardized } \\
\text { Coeff icients }\end{array}$} & & \\
\cline { 2 - 4 } & & \multicolumn{1}{|c|}{$\mathrm{B}$} & Std. Error & \multicolumn{1}{|c|}{ Beta } & \multicolumn{1}{c|}{ Sig. } \\
\hline 1 & (Constant) & 13.024 & 4.465 & & 2.917 & .027 \\
& Inf lasi & -.079 & .214 & -.164 & -.367 & .726 \\
& Output (In PDB Berlaku & -4.665 & 3.647 & -.571 & -1.279 & .248 \\
\hline
\end{tabular}

a. Dependent Variable: BI Rate

Dari tabel diatas didapat persamaan regresi dengan pendekatan Taylor :

$Y=13,024-0,079 X_{1}-4,665 X_{2}+$ e.

Dari uji regresi atas data diatas, maka dapatlah dijelaskan bahwa variable $\mathrm{X}_{1}$ (Inflasi) dan $\mathrm{X}_{2}$ (Output) berpengaruh negative terhadap variabel $\mathrm{Y}$ (Tingkat bunga riil). Hal ini berarti bahwa apabila terjadi kenaikan point pada variable bebas, maka hal ini akan berdampak kepada penurunan point pada variabel terikat.

Sebagai ilustrasi tambahan, apabila terjadi inflasi, Produk Domestic Bruto (output) akan turun, hal ini diakibatkan oleh tingginya harga factor produksi dan ini berdampak langsung secara cakupan mikro kepada output yang dihasilkan perusahaan dan secara mikro akan berdampak kepada output yang dihasilkan secara nasional (cakupan makro), jika hal ini telah terjadi, maka pihak Bank Indonesia akan menurunkan tingkat suku bunganya. Harapannya adalah jika tingkat suku bunga Bank Indonesia diturunkan, akan meningkatkan minat masyarakat untuk melakukan pinjaman kepada pihak perbankan yang nantinya dana pinjaman ini akan digunakan untuk membuka usaha baru maupun melakukan investasi. Dampak akhirnya adalah dapat meningkatkan kembali output yang menurun disebabkan oleh inflasi.

b. Uji Hipotesis Variabel.

\begin{tabular}{|c|c|c|c|c|c|c|}
\hline \multicolumn{7}{|c|}{ ANOVAP } \\
\hline Model & & $\begin{array}{l}\text { Sum of } \\
\text { Squares }\end{array}$ & $\mathrm{df}$ & Mean Square & $\mathrm{F}$ & Sig. \\
\hline 1 & $\begin{array}{l}\text { Regression } \\
\text { Residual } \\
\text { Total }\end{array}$ & $\begin{array}{r}8.494 \\
26.926 \\
35.420\end{array}$ & $\begin{array}{l}2 \\
6 \\
8\end{array}$ & $\begin{array}{r}4.247 \\
4.488\end{array}$ & .946 & $-439^{9}$ \\
\hline
\end{tabular}

b. Dependent Variable: BI Rate 
Hipotesis Dengan Pendekatan Taylor Rule:

- Ha diterima dan Ho ditolak, apabila $F_{\text {hitung }}>F_{\text {table }}$ (Nilai Sig. dibawah 0,05), maka tingkat suku bunga akan naik ketika output diatas normal, dan sebaliknya, tingkat suku bunga akan turun apabila output berada dibawah normal.

- Ho diterima dan Ha ditolak, apabila $F_{\text {hitung }}<F_{\text {table }}$ (Nilai Sig. diatas 0,05) maka tingkat suku bunga akan turun ketika output diatas normal, dan sebaliknya, tingkat suku bunga akan naik apabila output berada dibawah normal.

Hipotesis variable dengan menggunakan uji $\mathrm{F}$, dapat disimpulkan Ho diterima dan Ha ditolak, apabila $F_{\text {hitung }}<F_{\text {table }}$ (Nilai Sig. diatas 0,05) maka tingkat suku bunga akan turun ketika output diatas normal, dan sebaliknya, tingkat suku bunga akan naik apabila output berada dibawah normal.

Hal ini menyatakan bahwa uji signifikansi antara variable bebas dan variable terikat yang dilakukan melalui uji $f$ (Anova) menyatakan bahwa ketentuan pendekatan Taylor Rule tidak signifikan berpengaruh, walaupun secara penjelasan diatas antar variable memiliki hubungan secara negatif. c. Uji Koefisien Determinasi $\left(\mathrm{R}^{2}\right)$.

Model Summary

\begin{tabular}{|l|c|c|c|c|}
\hline Model & $\mathrm{R}$ & $\mathrm{R}$ Square & $\begin{array}{c}\text { Adjusted } \\
\mathrm{R} \text { Square }\end{array}$ & $\begin{array}{r}\text { Std. Error of } \\
\text { the Estimate }\end{array}$ \\
\hline 1 & $.490^{\mathrm{a}}$ & .240 & -.014 & 2.11840 \\
\hline \multicolumn{4}{|c}{ a. Predictors: (Constant), Output (In PDB Berlaku - Ln } \\
PDB Konstan), Inf lasi
\end{tabular}

Dari uji koefisien determinasi diatas didapatkan angka koefisien determinasi menunjukkan angka sebesar 0,240 atau $24 \%$, Hasil penelitian ini menjelaskan bahwa Variable Bebas mampu untuk menjelaskan variable terikat sebesar 0,240 atau $24 \%$, dan terdapat $76 \%$ variabel lain yang dapat juga menjelaskan variabel terikat tetapi tidak dimasukkan kedalam uji model pada penelitian ini.

\section{Kesimpulan dan Saran}

\subsection{Kesimpulan}

Kesimpulan dari analisis regresi dengan menggunakan pendekatan Taylor Rule, maka dapat disimpulkan bahwa Variabel Bebas (Inflasi dan Output) berpengaruh secara negative slope terhadap Variabel Terikat (Tingkat Suku Bunga Riil), hal ini berarti setiap penambahan/kenaikan nominal pada variable Inflasi dan Output maka akan menyebabkan tingkat suku bunga riilakan turun. Pengaruh antar variable bebas terhadap variable terikat sebesar 0,240 atau 24\%, hal ini dapat dikatakan variable bebas memiliki pengaruh yang relative kecil dalam mempengaruhi pergerakan variable terikat.Untuk uji hipotesis, variable bebas tidak berpengaruh secara signifikan terhadap variable terikat.

\subsection{Saran}

Untuk lebih mengembangkan pemahaman tentang konsep dan aplikasi teori ekonomi makro khususnya materi kebijakan moneter dengan menggunakan pendekatan “Taylor Rule" di Indonesia, disarankan kepada peneliti lain agar dapat melakukan analisis kebijakan moneter dengan beberapa pendekatan lain sebagai konsep materi pembanding sehingga memberikan hasil yang lebih komprehensif bagi optimalisasi kebijakan moneter di Indonesia. 


\section{Daftar Pustaka}

Romer, David. 2006. Advanced Macroeconomics : Third Edition. New York. The McGraw-Hill Companies.

Murwani, Sri. 2007. Analisis Kebijakan Moneter Kaitannya Dengan Penanaman Modal Asing: Pendekatan Taylor Rule. Tesis. Program Pascasarjana Universitas Diponegoro Semarang. Semarang.
Gujarati dan Porter. 2009. Dasar-dasar ekonometrika. Jakarta : salemba empat.

BPSIndonesia. 2014. Indonesia dalam Angka Tahun 2014.

Bank Indonesia. 2014. Statistik Ekonomi dan Keuangan Indonesia.

Bank Indonesia. 2014. Laporan Perekonomian Indonesia. 